\title{
4. 臨床研究における観察研究とランダム化比較試験
}

\author{
名 郷 直 樹*
}

\section{1. はじめに}

EBM の登場は，臨床現場において，病態生理だけでな く, 臨床研究のエビデンスも参考にしながら診療するとい うスタイルの普及に役立った。 その反面，ランダム化比較 試験（Randomized Controlled Trial：RCT）だけがエビデ ンスであるというような誤解もきたし，さまざまな問題も 明らかになってきている。

本稿では, 臨床における $\mathrm{EBM}$ の実践において, EBM= $\mathrm{RCT}$ というような根強い誤解を解き, 観察研究と RCT の 関係，現場での利用法を，具体例を用いながら解説するこ とにより，より実践的な EBM の実際をお示ししたい。

\section{2. 観察研究結果と RCT の結果の不一致}

常に RCT が観察研究より優れている，常にRCTによ る検討が必要である, というのは明らかな誤解である. 問 題は, どういうときにRCTによる検討が必要か, どうい うときは観察研究がいいのかということである.

臨床研究で RCT の重要性を強調する時代は終わり, 臨 床研究全体の中での RCT の役割を知ることが重要な時代 へと, 一歩進んでいかなくてはならない. そこで, まず観 察研究の結果と RCT の結果の一致を検討したメ夕分析の 結果，あるいはその $2 つ に$ 不一致がみられた実例を見てみ よう.

2000 年に内科領域 ${ }^{1)} て ゙, 2006$ 年には外科領域)でも, 観 察研究と RCT で効果に差がないというメ夕分析が発表さ れた.こうしたメ夕分析からすれば, 優れたコホート研究 があれば，何も莫大な資金や時間をかけて RCT を行うの は無䭾のようにも思われる. しかし, それに対し， 25 の観 察研究のうち, 3 つは観察研究において認められた治療効 果の信頼区間に, RCT の点推定值が含まれなかっだ3)とい うメタ分析も発表されている. 個別の例としては, 観察研 究でがんの予防が予想された $\beta$ カロチン, 女性の閉経後の 心疾患の減少効果を期待されたホルモン補充療法が, RCT の検討では, いずれも効果がないばかりか, かえって害が

* 社団法人地域医療振興協会

東京北社会保険病院臨床研修センター

于 115-0053 東京都北区赤羽台 4-17-56
あるという結果を示した事実がある ${ }^{4,5)}$.

これらのメタ分析の結果からすれば，常に RCT の検討 が必要なわけではないが, 観察研究の結果だけで十分とも いえないということである，それでは，どんなときに $\mathrm{RCT}$ での検討が必要なのか, 次にそれについて考えてみ たい.

\section{3. 観察研究で劇的な効果が認められる場合}

観察研究で十分かどうかという検討を, 劇的な治療効果 の定義という形でまとめている論文がある ${ }^{6)}$ ．その論文で は，まず ‘All or none’ criteria，つまり自然経過では全員 が死亡, イベント発症, 治療により全員生存, イベント発 症なしというような結果が, 観察研究で得られた場合，ま た，それほど極端な効果でなくても，アウトカムの発生が $1 / 100$ 以下に減少, 相対的な治療効果が 10 倍以上の場合, バイアスのみで 10 倍の差を説明できることはまれで，こ のような場合を，劇的な治療効果と定義している。そうな ると，やはり多くの場合 RCT での評価が必要ということ になる。

\section{RCT でしか評価が困難な場合}

逆に RCT 以外では評価が困難な場合についても，日本 人に高コレステロール血症の一次予防の RCT T゙ある MEGA Study ${ }^{7)}$ を例に考えてみる.

この研究結果は, 年率 $0.5 \%$ の冠動脈疾患を $0.33 \%$ に減 少させるというものであるが, このような差を明らかにす るためには，バイアスの影響の大きい観察研究では困難で ある．調整できていない未知の交絡因子の影響による小さ な差という疑いを晴らすことは難しいからである。こうし た状況では, RCTが必要だろう.

しかし，ここで少し立ち止まって考えてみる必要がある. 確かにこのようなわずかな治療効果は大規模な RCT でし か明らかにできない.ただ，このような小さな差を明らか にする意味が, 臨床的にあるかどうか，という疑問が残る. 観察研究で女性の冠動脈疾患の罹患率が $0.5 \%$ とさい, ということが分かった時点で, そのようなリスクの小さい 人を対象とした RCT の検討に臨床上意味はない, という 
判断も可能ではないかと思われる．医療費は有限であり， 少しでも有効なら何でもかんでも検討すればよいとは言え ないからである。

\section{5. 観察研究が勝る場合}

\section{1 ）予後の検討}

承諾が得られた人のみが参加する RCT では，対象患者 の代表性に問題があり，予後の推定には不適切な面がある. $\mathrm{RCT}$ の対照群から見積もられる带状疮疹後神経痛の頻度 は 9 15\%であるが8)，一般医の受診者を対象としたコホー 卜研究では $1.8 \%$ にすぎないという結果である ${ }^{9,10)}$.これ は，急性疾患ではより重篤な人が臨床試験に参加しやすい というバイアスが関係していると考えられる.

また逆にがんのスクリーニングなどでは，スクリーニン グの臨床試験に参加する人はより健康意識が高く，一般住 民のがんの死亡リスクを見積もるには健康すぎる集団で, この場合もやはりコホート研究の結果のほうが, がんの死 亡リスクを見積もるのに適していると考えられる

\section{2 ) 副作用の検討}

頻度の少ない副作用の検討を， RCT で行うことは困難 である。それほど少なくなくても，臨床試験でサンプルサ イズの検討に用いられたエンドポイントより頻度が低い副 作用については, 統計学的な差を検出できる可能性は低い.

スタチンによる横紋筋融解の検討を例に考えてみる．先 ほどの $\mathrm{MEGA}^{7}$ では横紋筋融解の報告はされていない。し かし，これだけでスタチンで横紋筋融解の危険はないと結 論できない。そこでメ夕分析の結果もみてみる。両群の発 症率が $0.1 \%$ (対照) と $0.2 \%$ (スタチン) とスタチンで多 い傾向にあるが，有意差なしという結果である ${ }^{11)}$ 。まれに しか起きないが，重大な副作用についてはこれでも不十分 である.さらに観察研究を付け加えて, ようやく $0.15 / 100$ 万処方に横紋筋融解による死亡例があるという報告 ${ }^{12}$ がな され，数万人レベルのメ夕分析でも検討不能であることが わかる。十分な数のまれな副作用をとらえるためには, RCT のメ夕分析を超え, 観察研究を含めすべての処方を 検討した観察研究が最も現実的な方法である。もちろんバ イアスの可能性は大きくなるが, コレステロールのように 無症状な状態に対する副作用については，疑わしい副作用 を漏れなく考虑したほうがいいと考えるのが臨床的であ る.

\section{RCT の結果の観察研究による検証}

観察研究は, RCT が必要かどうかの検討, 効果の見積も りをして, 研究規模を決めるためにも重要である。しかし, それだけではない，RCT の結果が出た後にも，観察研究
は重要である. RCT は, 参加の承諾が得られた, どちらか というと治療に積極的な, 理想的な患者群で, 理想的な医 療環境で行われることが多い. そうした理想的な患者群, 理想的な医療環境で行われた RCT の結果が, 現実の臨床 現場に適応できるかという重大な問題が残る。そうした例 を見てみよう。

1991 年に高齢者の孤立性高血圧に対して, 利尿薬を第一 選択, $\beta$ 遮断薬を第二選択としたステップケアで治療して, 脳卒中を $30 \%$ 以上減少させるという RCT が発表され $た^{13)}$.

臨床試験では, 利尿薬は低用量の投与にとどめ, カリウ ムのフォローが厳密に行われたが, 臨床の現場では, 必ず しも低用量が守られず，カリウムのチェックもそれほどな されないとなると，本当に臨床試験と同様な効果が得られ るかどうかは疑問である。事実，その後の観察研究で，利 尿薬は用量依存性に突然死の危険を増加させ，低用量を守 るか，カリウム保持性の利尿薬を併用しないと，突然死の 危険が増加することが示された ${ }^{14)}$. RCT の結果を闇雲に 現実の臨床に適応していくことの危険は，その後の観察研 究で明らかになるという例である。

\section{7. まとめ}

観察研究と RCT を必要に応じて使い分けることが重要 である．交絡因子を排除して治療効果を検討できる RCT の意義は大きいが，予後や副作用の検討では，むしろ不適 切な面がある。また理想的な環境で行われた RCT で検証 された治療が，現実の臨床現場では意外な結果をもたらす ことがあり，その検討には RCT 後の観察研究が重要であ る.

\section{文献}

1) Benson K, et al. N Engl J Med $2000 ; 342: 1878-86$.

2) Shikata S, et al. Ann Surg $2006 ; 244: 668-76$.

3) Ioannidis JP, et al. BMJ $2001 ; 322: 879-80$.

4) The Alpha-Tocopherol, Beta Carotene Cancer Prevention Study Group. N Engl J Med 1994 ; 330 : 1029-35.

5) Rossouw JE, et al. JAMA. $2002 ; 288: 321-33$.

6) Glasziou P, et al. BMJ 2007 ; $334: 349-51$.

7) Nakamura H, et al ; MEGA Study Group. Lancet 2006 ; 368 (9542) : 1155-63.

8) Lancaster T, et al. Br J Gen Pract 1995 ; 45(390) : 39-45.

9) Helgason S, et al. BMJ $2000 ; 321$ (7264) : 794-6.

10) Pfeffer MA, et al. Circulation $2002 ; 105: 2341-6$.

11) Kashani A, et al. Circulation 2006 ; $114: 2788-97$.

12) Staffa JA, et al. $N$ Engl J Med $2002 ; 346: 539-40$.

13) SHEP Cooperative Research Group. JAMA $1991 ; 265: 3255-64$.

14) Siscovick DS, et al. N Engl J Med $1994 ; 330: 1852-7$. 